\title{
THE FALLACY OF ACCESSIBILITY
}

\author{
by W. Flint Smith and Ellon Hoiking
}

Since 1960, and especially in the last three years, a wide variety of electromechanical devices have been designed to facilitate second-language learning. An increasingly popular installation, primarily because it places the "hardware" within the foreign language classroom, is the wired or wireless "electronic classroom," although the term is somewhat ambiguous and by no means new.

For the following discussion the clectronic classroom is defined as an integrated group of wired electronic components, with no booths or tape recorders for the student, but with an audio-activated headset and microphone at each desk; for the teacher there is a permanently installed control console with multiple program sources and monitor-intercom switches. All the equipment for the student is retractable, in "chandeliers," up to the ceiling. The electronic classroom is therefore immediately convertible for other subject-matter instruction.

At first glance, such an arrangement would seem to have these further advantages (Regenstreif, 1968): It is inexpensive in original cost and in maintenance; it uses already available space; best of all, it is immediately accessible, so that the teacher can provide distributed practice with recorded materials at precisely those times judged to be most opportune, regardless of room schedules or the length of class periods. It follows that the migration of students to and from the laboratory, in "split-period" sessions, is obviated.

The total amount of time devoted to such practice has repeatedly been shown to be a significant factor in language learning (Birkmaier and Lange, 1967). The frequency of practice sessions is probably no less important. Stack (1966) recommends twenty to thirty minutes of laboratory practice each day; yet several broad field surveys have shown that the recommended minimum is rarely achieved (Keating, 196.3; Gaarder and Hutchinson, 1964).

The electronic classroom would seem to offer a better chance for such frequent and intensive practice. Although lacking published studies of this subject, one would expect that the greater accessibility of the equipment would lead to greater and better use of it (Smith and Littlefield, 1967). But thanks to a recent investigation (Smith, 1969), we now have evidence that such is not necessarily the case. We refer to an investigation designed to assess the relative efficacy of (1) the broad- 
cast lab; (2) the record-playback lab; and (3) the "chandelier-type" electronic classroom.

The locale was a comprehensive high school with first-year students in three languages. One teacher each of French, German, and Spanish was randomly assigned a minimum of two groups, one of which met daily in an electronics classroom; the other met in a conventional classroom but migrated to either a record-playback or a broadcast language laboratory. In each language, instructional materials were identical.

A maximum of seventy-five minutes per week was allotted to machine-guided practice. In the electronic classroom groups the teachers were free to distribute such practice as they saw fit; in the other groups, however, a rigorous laboratory schedule was prescribed. All teachers were asked to record daily the number of minutes and the mode in which the respective equipment was used; totals were tabulated and compared at the end of each six-week grading period (see Table).

\section{TABLE}

Application of the Electronic Classroom and the Language Laboratory: Minutes Use per Six Weeks.

\begin{tabular}{cccccccccc} 
Six weck & \multicolumn{3}{c}{ FRENCH } & \multicolumn{3}{c}{ GERMAN } & & \multicolumn{2}{c}{ SPANISH } \\
period & EC & L.L.-1 & LL-2/RP & EC-1 & EC-2 & LL-1 & L.L-2/RP & EC & LL-2/RP \\
1 & 100 & 150 & $150 / 30$ & 280 & 150 & 165 & $195 / 75$ & 247 & $326 / 115$ \\
2 & 175 & 200 & $200 / 55$ & 323 & 130 & 100 & $155 / 65$ & 281 & $241 / 90$ \\
3 & 300 & 300 & $300 / 100$ & 245 & 265 & 225 & $250 / 30$ & 237 & $291 / 91$ \\
4 & 300 & 300 & $300 / 95$ & 235 & 300 & 320 & $385 / 70$ & 352 & $361 / 97$ \\
5 & 225 & 250 & $250 / 95$ & 055 & 300 & 270 & $290 / 25$ & 319 & $314 / 89$ \\
6 & 200 & 225 & $265 / 90$ & 190 & 274 & 270 & $270 / 50$ & 381 & $402 / 108$ \\
\hline Totals & 1300 & 1425 & $1465 / 465$ & 1328 & 1415 & 1350 & $1545 / 315$ & 1817 & $1937 / 600$
\end{tabular}

Average Use by All Equipment Groups :

French 1397 minutes; German 1410 minutes; Spanish 1877 minutes

Use of Record-Playback facilities.

In all languages, weekly use of the tape-recorder materials fell below the recommended maximum, varying from 25 to 65 minutes; the median use was 45 . In total time, the Spanish students received some 25 percent more machine-guided practice than either French or German - a difference readily explained by the "visual-audio-lingual" materials which required the presentation of sound films, filmstrips and taped exercises. When compared among groups within each language ${ }^{1}$ there was no significant difference $(p .05)$ in the amount of time the respective equipment was used. It is noteworthy, however, that contrary to 
expectations the electronic classroom groups generally made less total use of the equipment than the language laboratory groups. Convenient access to the equipment was apparently not an important factor in the amount of time the facilities were actually used.

This outcome would seem to re-emphasize the need for scheduled use of equipment. It seems probable that the very accessibility of the "chandelier" equipment obviated, in the teachers' mind, the need for systematic planning. Additionally, there was some evidence that the electronic classroom equipment was used in modules of ten minutes or less (Smith, 1969, pp. 83-85). Yet it would seem that any use of recorded materials should be long enough for the students to achieve full concentration and for the teacher to evaluate, via the monitor-intecom, the students' responses. Moreover, the frequent and fragmented use of the equipment may waste as much time as one trip to the language laboratory. This is especially the case when the student headsets must be passed out and collected each time the equipment is used. Finally, one may theorize that a practice session of less than fifteen minutes will also diminish the scope and the sequence of the unit under study.

It seems clear, therefore, that ease of access to equipment makes no less important the need to plan how each session of machine-guided practice is to be integrated into the instructional sequence, and that improvisation can impede learning.

${ }^{1}$ Kruskal-Wallis one-way analysis of variance (Siegel 1956, PP. 184-93). 


\section{Bibliography}

Birkmaier, E. M. and Lange, D. L. "Foreign Language Instruction." Review of Educational Research 37:186-99; 1967.

Gaarder, A. B. and Hutchinson, J. C. A Pilot Survey of Foreign Language Teaching Equipment in 16 States. Mimeo, available from author, 1964.

Keating, R. F. A Study of the Effectiveness of Language Laboratories: A Preliminary Evaluation in Twenty-one School Systems of the Metropolitan School Study Council. New York: Institute of Administrative Research, Teachers' College, Columbia University, 1963.

Regenstreif, $\mathrm{H}$. "The Language Laboratory vs. the Electronic Classroom." National Association of Language Laboratory Directors' Newsletter 2:14-17, 1968.

Siegel, S. Non-parametric Statistics for the Bebavioral Scienses. New York: McGraw-Hill Book Co., 1956.

Smith, W. F. The Language Laboratory and the Electronic Classroom: A Comparison of the Relative Contribution to Acbievement in Three Languages in the Comprebensive High School. (Unpublished Ph.D. dissertation) Purdue University, 1969.

Smith, W. F. and Littlefield, R. L. The Language Laboratory and the Electronic Classroom: A Comparison. A Report to the Indiana Language Program, Indiana University, Bloomington, 1967.

Stack, E. M. Language Laboratory and Modern Language Teacbing. New York: Oxford University Press, 1966.

ABOUT THE AUTHORS: William Flint Smith is Director of Language Laboratories and Assistant Professor of Spanish at Purdue University, Lafayette, Indiana.. Elton Hocking is Professor of Modern Language Education at Purdue University, Lafayette, Indiana. 